\title{
High diatom species turnover in a Baltic Sea rock pool metacommunity
}

\author{
Sonja Aarnio ${ }^{1}$ (D) - Anette Teittinen ${ }^{1} \cdot$ Janne Soininen $^{1}$
}

Received: 3 July 2019 / Revised: 17 September 2019 / Accepted: 21 September 2019/Published online: 19 November 2019

(C) The Author(s) 2019

\begin{abstract}
Different metacommunity perspectives have been developed to describe the relationship between environmental and spatial factors and their relative roles for local communities. However, only little is known about temporal variation in metacommunities and their underlying drivers. We examined temporal variation in the relative roles of environmental and spatial factors for diatom community composition among brackish-watered rock pools on the Baltic Sea coast over a 3-month period. We used a combination of direct ordination, variation partition, and Mantel tests to investigate the metacommunity patterns. The studied communities housed a mixture of freshwater, brackish, and marine species, with a decreasing share of salinity tolerant species along both temporal and spatial gradients. The community composition was explained by both environmental and spatial variables (especially conductivity and distance from the sea) in each month; the joint effect of these factors was consistently larger than the pure effects of either variable group. Community similarity was related to both environmental and spatial distance between the pools even when the other variable group was controlled for. The relative influence of environmental factors increased with time, accounting for the largest share of the variation in species composition and distance decay of similarity in July. Metacommunity organization in the studied rock pools was probably largely explained by a combination of species sorting and mass effect given the small spatial study scale. The found strong distance decay of community similarity indicates spatially highly heterogeneous diatom communities mainly driven by temporally varying conductivity gradient at the marine-freshwater transition zone.
\end{abstract}

Keywords Brackish $\cdot$ Conductivity $\cdot$ Mass effect $\cdot$ Microbial $\cdot$ Species sorting $\cdot$ Temporal

\section{Introduction}

Microbial communities contribute to a variety of biogeochemical processes vital for the functioning of ecosystems. Variation among these communities thus potentially affects the whole ecosystem, and better knowledge of the key factors determining microbial communities is urgently needed (Van der Gucht et al. 2007). Due to their high diversity, relatively well-defined habitat preferences, short generation times, and generally-yet not

Communicated by B. Beszteri

Electronic supplementary material The online version of this article (https://doi.org/10.1007/s12526-019-01016-z) contains supplementary material, which is available to authorized users.

Sonja Aarnio

sonja.aarnio@helsinki.fi

1 Department of Geosciences and Geography, University of Helsinki, P.O. Box 64, FI-00014 Helsinki, Finland invariably - geographically wide distribution, microbial algae such as diatoms are useful model taxa in testing different ecological theories over short timescales (Smucker and Vis 2011). So far, studies of community dynamics and especially spatiotemporal variation in species composition for microbial eukaryotic organisms are still rare compared with those of macroorganisms (Martiny et al. 2006; Meier and Soininen 2014). A metacommunity consists of local communities occupying discrete habitat patches connected by potentially interacting species through dispersal (Hanski and Gilpin 1991; Leibold et al. 2004). Through the application of metacommunity theory, community-level patterns in species abundance, distribution and biotic interactions are tightly coupled and explained against the theoretical background of spatial and environmental processes on a scale of metacommunities (Leibold et al. 2004; Logue and Lindström 2008).

The current metacommunity theory comprises four conceptual archetypes, each reflecting variable roles of environmental and spatial factors for metacommunity dynamics. We note here that these archetypes form recognizable dynamics in 
a continuum of metacommunity parameter space rather than discrete paradigms (Logue et al. 2011). Neutral theory (Hubbell 2001) stresses the importance of spatial processes in regulating metacommunities (Chave 2004; Cottenie 2005). Species are thought to be equal in their environmental demands, and random stochastic events related to dispersal or births and deaths are the only determinants of species distribution. According to species sorting, each species has specific tolerance toward environmental conditions expressed by ecological niches, separating species to environmentally varying habitat patches (Leibold et al. 2004). Species dispersal rate is low enough not to hold the dominating role in community regulation (Logue et al. 2011) and acts in the shadow of more powerful environmental processes, enabling species to reach suitable sites while not resulting in independent spatial patterns in a metacommunity (Cottenie and De Meester 2004; Cottenie 2005). The mass effect perspective (Shmida and Wilson 1985) involves both species dispersal and environmental factors as being responsible for a community organization (Leibold et al. 2004). As environmental preferences divide species to their local habitats, dispersal between patches maintains the viability of communities by enabling temporary species occurrence outside their preferred distribution ranges (Pulliam 2000; Logue et al. 2011). The fourth archetype, that of patch dynamics (Leibold et al. 2004), emphasizes dispersal limitation as in control of local species diversity among identical patches, either occupied or unoccupied according to local extinction-colonization dynamics.

Although many studies have now addressed the metacommunity structure in different types of ecosystems, temporal variation in metacommunity structure and the underlying factors are still poorly studied (but see, e.g., Azeria and Kolasa 2008; Vanschoenwinkel et al. 2010; Langenheder et al. 2012) and occasionally weakly connected to variation in species composition (Padial et al. 2014). Specifically, the dependence of spatial variables such as pool connectivity on temporal variability in local precipitation patterns and consequent changes in dispersal rates between sites may alter species composition and turnover rate especially in coastal communities (Langenheder et al. 2012). Ecosystems are expected to face rapid changes in the current era of global warming, highlighting the need for metacommunity-level information about temporal and spatial variation in and their effects on species composition and turnover rate not limited by snapshot sampling. Two metrics-halving distance and initial similarity - developed to describe patterns of distance decay between communities give cues about species turnover more effectively than traditional correlation coefficients. Limited dispersal or high environmental heterogeneity between sites results in faster decrease in community similarity along environmental and spatial distance and higher turnover rate, characterized by low initial similarity and short halving distance (Soininen et al. 2007; Wetzel et al. 2012).
For investigating metacommunity dynamics, granitic rock pools provide an ideal model system. These are geologically old formations occurring as ubiquitously scattered depressions on rocky outcrops typically surrounded by sea (Jocque et al. 2006). Despite their small size, these physically and biologically diverse waterbodies form a disproportionately large share of regional-scale aquatic biodiversity (Blaustein and Schwartz 2001; Brendonck et al. 2016). As hierarchically nested and closely located depressions, each rock pool serves as a small-scale community connected by species dispersal within a metacommunity (Blaustein and Schwartz 2001). During the last decade, the potential of rock pools as ecological model systems has been shown (Vanschoenwinkel et al. 2007). Representative sampling and a quantification of community dynamics and dispersal processes is more effortless and more easily replicated in time than in larger and more complex aquatic systems and study results are also usually comparable and easily interpolated to different spatial scales (Srivastava et al. 2004; De Meester et al. 2005).

This study aimed to examine temporal variation in the relative roles of environmental and spatial factors for a metacommunity composition. Specifically, this study aimed to answer to the following research questions: First, which environmental and spatial variables affect the community composition in rock pools over time? Second, how do rock pool diatom community similarities vary along the environmental and spatial gradients over time? Third, which metacommunity archetype or a combination of archetypes best explain the observed variation among the rock pool diatom communities?

\section{Material and methods}

\section{Study area}

The study area consisted of 30 granitic rock pools on a rocky outcrop (ca. $1200 \mathrm{~m}^{2}$ ) on the western island of Pihlajasaari $\left(60^{\circ} 8^{\prime} 10^{\prime \prime} \mathrm{N}, 24^{\circ} 54^{\prime} 46^{\prime \prime} \mathrm{E}\right)$, located approximately $2 \mathrm{~km}$ south of Helsinki, Finland, and surrounded by the northern part of the Baltic Sea, the Gulf of Finland (salinity ca. 5\%o) (Fig. 1). Tidal influence in the area is virtually absent, and changes of sea level are mainly caused by wind and differences in air pressure. The majority of the studied pools were located at or close to the sea surface level ( $<5 \mathrm{~m}$ a.s.1.). Pools of varying size and location were chosen for the study and named by running numbers from 1 to 35 . As pools 31-34 dried up until the first sampling in May and pool 24 was merged with pool 22 by a rainfall-induced overflow from June onwards, the data consist of pools 1-23, 25-30, and 35 (Online Resource 1).

The majority of the pools were rainfall-fed, but the pools closest to the sea were directly influenced by brackish 


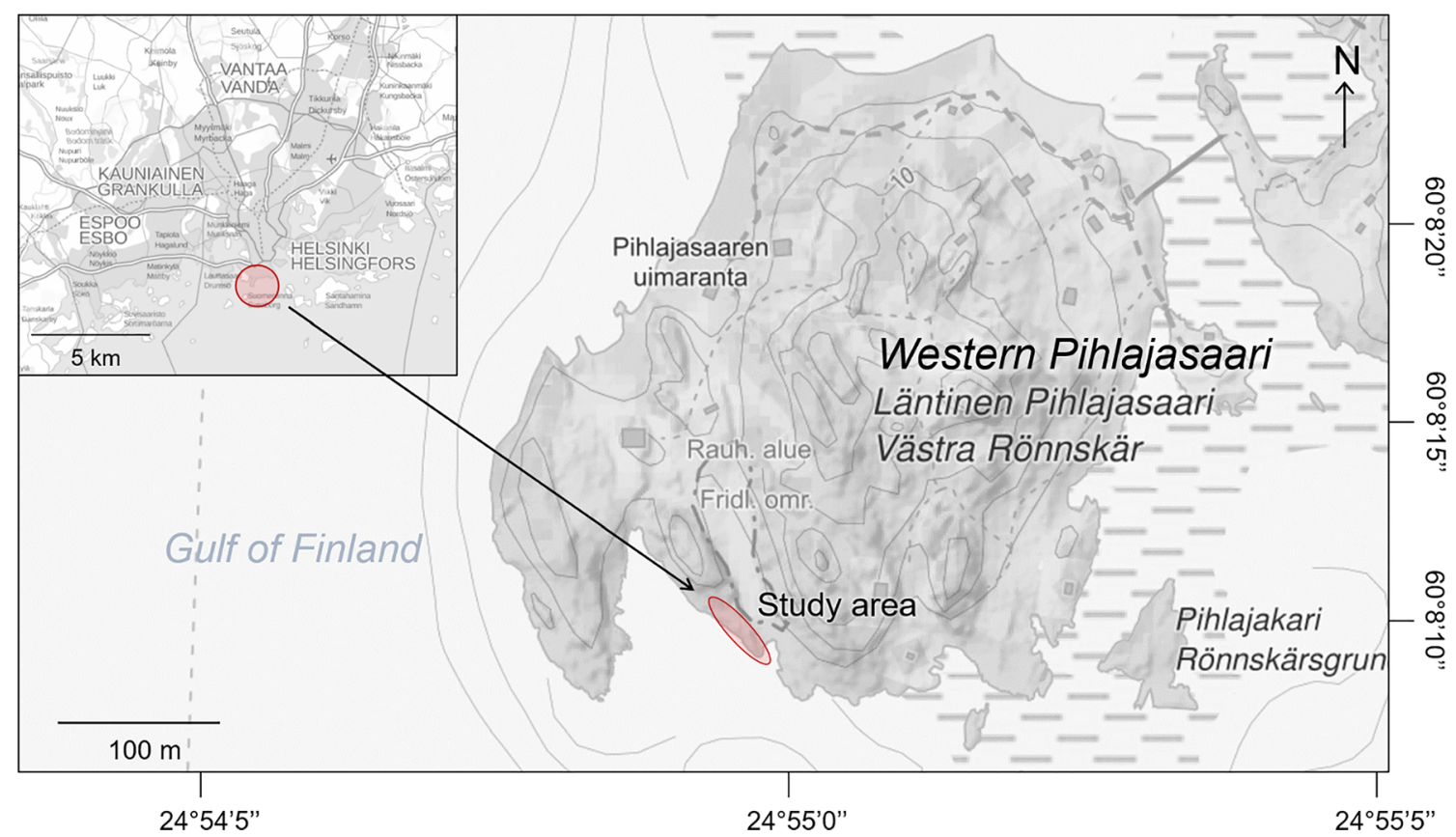

Fig. 1 A map of the study area. The study area is located on the Western Pihlajasaari island c. $2 \mathrm{~km}$ off the coast of Helsinki (red circle on the index map) on a rocky outcrop on the southwestern part of the island (red oval on the larger map). Map: National Land Survey of Finland (2018)

seawater by wind-caused waves and indirectly by salty sprays from the sea (Fig. 2). Despite merging of the pools 22 and 24 after May, the pools were isolated from each other and not permanently interconnected by watercourses. Due to an impermeable granitic pool base, groundwater influence was virtually absent, as was surface outflow from the surroundings in the absence of any nearby freshwater sources. The pools were not shaded by the sparse vegetation, making solar radiation conditions comparable. Nutrient enrichment was likely mostly of a faunal origin, caused by excrements and decaying remains of aquatic insects and their larvae and nutrient inputs from, e.g., tadpoles, bird droppings, and other animal feces (Methratta 2004; Brendonck et al. 2016).

\section{Field sampling}

The field data were collected once a month on 17 May, 22 June, and 22 July 2016. The environmental data consist of water physicochemical characteristics $(\mathrm{pH}$, conductivity, temperature, total $\mathrm{P}$, and total $\mathrm{N}$ ) measured in the field with YSI field meter and pool size measurements (max length, width, and depth) measured with a meter stick to the nearest centimeter. Pool area was calculated by multiplying pool length by pool width. For two very irregularly shaped pools (pools 10 and 12), means of multiple measurements of both pool width and length were used to better reflect the real pool surface area. A 0.5-L water sample was collected from each pool in a plastic container and preserved at $4{ }^{\circ} \mathrm{C}$ until the determination of total P following standard SFS-EN ISO 6878 (2004) and total N following standard SFS-EN ISO 11905-1 (1998) in a laboratory. The determination of total $\mathrm{N}$ was occasionally disturbed by high organic matter content, which, like nitrogen, also absorbs radiation on the UV wavelength of $220 \mathrm{~nm}$ measured by the UV/VIS spectrometer. Due to such a high disturbance in 21 samples (15 in June and 6 in July) and two results exceeding the determination limit in May, all total $\mathrm{N}$ values were omitted from the data.

The spatial data consisted of pool $X$ and $Y$ coordinates and mean isolation. Due to the very small spatial scale of the study and consequent difficulties in determining the exact pool coordinates by GPS or from aerial photographs, the coordinates were estimated from a drawn grid map of the study area showing the relative location of the pools to each other and to the seashore. $X$ coordinates were based on perpendicular pool distance from the shore, while $Y$ coordinates described horizontal pool distance from the map origin (the south end) parallel to the shoreline. The relative isolation was calculated for each pool as a mean Euclidean distance, i.e., the sum of distances to five closest pools divided by five (Vanschoenwinkel et al. 2007).

The benthic diatoms were sampled following EN 13946 standard (2003). Ten epilithic subsamples of c. $25-\mathrm{cm}^{2}$ area were collected by a toothbrush from each pool and combined as a single composite sample in a plastic test tube in the field. The subsamples were collected from different sides of each pool from the pool bottom. From the two steepest-walled pools (pools 10 and 14) the pool bottom was unreachable and only the walls were sampled deep enough to ensure the frustules were permanently submerged. Between each sampling, the toothbrush was rinsed in pool water to remove any 

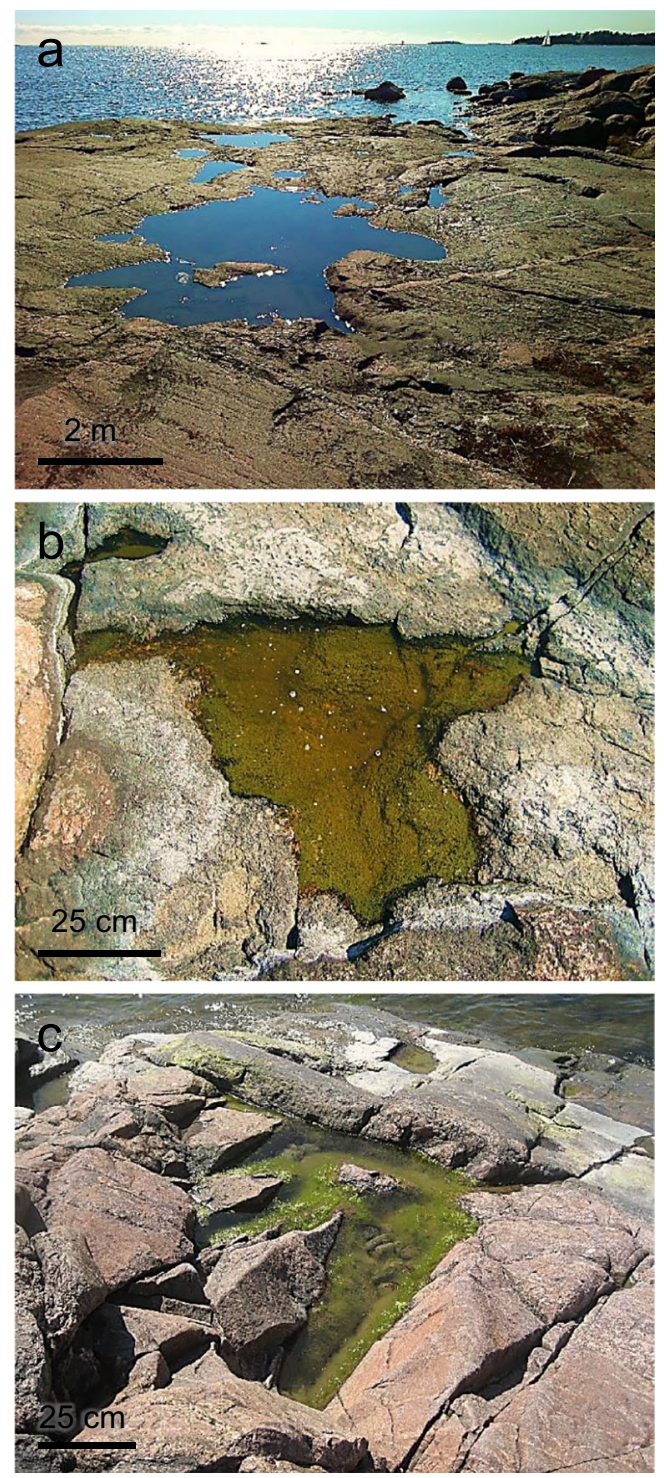

Fig. 2 Some of the studied rock pools on the rocky outcrop of the western Pihlajasaari island. a A view from the study area to the northern Gulf of Finland; b pool 5 with shallow $(0.15 \mathrm{~m})$, clear water, and visible bottom sediment; c pool 26 located at an immediate proximity to the sea with an exceptionally large coverage of macroalgae. Photos: a Anette Teittinen, b-c Sonja Aarnio

attached cells as this effectively reduces the possibility of contamination and taxonomical bias between the samples (Kelly et al. 1998). The samples were stored at $4{ }^{\circ} \mathrm{C}$ for $24 \mathrm{~h}$ until microscopical analyses. The samples were treated with $30 \%$ $\mathrm{H}_{2} \mathrm{O}_{2}$ to remove organic material and mounted on slides with Naphrax. A total of 500 frustules per slide were counted and identified to the lowest taxonomic level possible (mostly species level) with a light microscope with 1000-fold magnification following Krammer and Lange-Bertalot (1986-1991). From the four most sparsely slides celled, less than 500 frustules could be counted (pool $21(n=476)$ in June and pools 9 $(n=414), 11(n=385)$, and $20(n=156)$ in July). The total, absolute cell abundances were converted to relative percentages to make the cell numbers comparable with each other. The identified species were classified according to their preferences for water salinity into marine, brackish, and freshwater species, as well as species favoring both marine and freshwater environments (excluding 8 specimens identified to genus level and 1 Nitzschia specimen with an unknown salinity preference) mainly after Cantonati et al. (2017).

\section{Statistical analyses}

Prior to statistical analyses, normality of the explanatory variables was tested with the Shapiro-Wilk's normality test (Shapiro and Wilk 1965) and all the non-normally distributed explanatory variables (except $\mathrm{pH}$ ) were $\log _{10}$-transformed to reduce their skewness. Spearman's rank correlation coefficients were calculated to detect statistical dependence between the variables. In June, conductivity and $Y$ coordinates were strongly correlated $\left(r_{\mathrm{s}}=-0.79\right)$ and hence $Y$ coordinates were excluded from the June's statistical models (but included in the combined RDA model as the correlation between these variables was $<|0.7|$ in the combined dataset). Temporal fluctuations in pool physicochemical characteristics were compared with a short-term climate data from Kumpula meteorological station, Helsinki, including daily precipitation (mm), mean air temperature $\left({ }^{\circ} \mathrm{C}\right)$, and mean wind speed $\left(\mathrm{m} \mathrm{s}^{-1}\right)$ covering a 7-day period before each sampling (FMI 2017; Online Resource 2).

Spatial autocorrelation was calculated for the environmental variables by Moran's I (Moran 1950). Water salinity is an important factor regulating pool biota especially in coastal areas under significant seawater influence, and even minor changes along a pool conductivity gradient may have a major impact on communities (Vanormelingen et al. 2008). Thus, the distance to the sea $(X)$ was considered more important gradient than the horizontal distance along the shoreline $(Y)$. Since Moran's $I$ automatically calculates coefficients for the longest geographical gradient (i.e., $Y$ coordinates), the value of each $Y$ coordinate was set to zero while keeping $X$ coordinates unmodified. The data were divided into five distance classes at 2.5-m intervals. The $p$ values of the correlation coefficients were Bonferroni-corrected with a formula $\alpha^{\prime}=\alpha / k$, where $k$ is the number of distance classes and $\alpha$ the significance level of 0.05 (Legendre and Legendre 2012). Every correlation coefficient below $0.05 / 5 \approx 0.01$ was considered statistically significant.

The most influential explanatory variables for diatom community composition were examined with redundancy analyses (RDA; ter Braak 1994) with a Hellinger-transformed species data. An RDA is a direct gradient analysis in which species observations are directly related to a set of explanatory variables. An RDA was conducted separately with each monthly dataset; in addition, a fourth RDA was run for the combined dataset from May to July. The statistical 
significances of explanatory variables, ordination axes, and the model as a whole were assessed with the $F$ test with 999 permutations.

Variation partitioning (Borcard et al. 1992) was conducted for each monthly dataset and for the combined data to share the explained variation in community composition to fractions explained by pure spatial, pure environmental, and pure temporal factors (only for the combined data), as well as by their joint effect. The statistical significance of the fractions was assessed by RDAs run separately for each variable set using the $F$ test with 999 permutations (Legendre 1993).

Mantel tests (Mantel 1967) were performed to reveal the roles of spatial and environmental distance on community similarity (expressed using the Bray-Curtis dissimilarity index; Bray and Curtis 1957) in each month. Three distance matrices were created: a biotic dissimilarity matrix using species relative abundances, an environmental Euclidean distance matrix using water physicochemical characteristics and pool morphometrics, and a spatial Euclidean distance matrix using pool $X$ and $Y$ coordinates. Halving distances of community similarities were calculated with a formula $(\beta-\alpha) / 2 \beta$, where $\beta$ is the regression coefficient and $\alpha$ the intercept, and initial similarities were determined at a 1-m distance (Soininen et al. 2007) which was considered sufficiently long distance given the small study scale and short inter-pool distances. A partial Mantel test (Legendre and Legendre 2012) was conducted for each month with the same explanatory variables as in the Mantel tests. The partial Mantel test compares all three distance matrices simultaneously and divides the variation in distances among sites explained by pure environmental and pure spatial variables, while controlling for the effects of the other variable set. The significance of correlations for the Mantel and partial Mantel tests was assessed with 9999 permutations.

All statistical analyses were conducted with $\mathrm{R}$ (version 3.4.3; R Core Team 2018) with packages Hmisc (Harrell Jr 2018), pgirmess (Giraudoux et al. 2018), and vegan (Oksanen et al. 2018). All the graphs (Figs. 3, 4, 5, and 6) were created with R (version 3.4.3).

\section{Results}

High spatial and temporal environmental heterogeneity was detected among the rock pools throughout the study (Table 1 and Online Resource 3). In general, the studied pools were small $\left(<4.8 \mathrm{~m}^{2}\right)$, shallow $(\leq 0.4 \mathrm{~m}$ deep), eutrophic (mean total $\mathrm{P}>80 \mu \mathrm{g} \mathrm{L}^{-1}$ ), and alkaline (mean $\mathrm{pH}>7.5$ ). As it should be noted that the calculated pool area does unavoidably deviate from real pool surface area to some extent, the variable well reflected the relative size difference between the pools. Nutrient concentrations, conductivity, temperature, and $\mathrm{pH}$ were the highest in May; extremely high maximum values were recorded especially for conductivity $\left(16,741 \mu \mathrm{S} \mathrm{cm}^{-1}\right)$ and total P $\left(1448.3 \mu \mathrm{g} \mathrm{L}^{-1}\right)$. According to a principal component analysis (PCA), the variation in environmental variables was the lowest in July (the results not shown). The majority of the pools were located farther than $5 \mathrm{~m}$ from the seashore and not farther than $10 \mathrm{~m}$ from the five closest pools (Online Resource 4). Significant spatial autocorrelation (Bonferronicorrected $p<0.01$ ) was detected for water depth in June (Online Resource 5a) and for total $\mathrm{P}$, temperature, and conductivity in July (Online Resource 5b-d).

Monthly fluctuations in pool physicochemistry clearly reflected temporal variations in the local microclimate especially in May and June when compared with the short-term climate data from Kumpula meteorological station, Helsinki (Online Resource 2, 3). Higher air temperatures and low precipitation were followed by shallow and warm water with high conductivity and nutrient concentrations in May, while heavy rainfalls, higher wind speed, and lower air temperature decreased water temperatures and nutrient levels and increased pool depth in June. The studied pools followed a clear gradient in water conductivity along both $X\left(r_{\text {May }}=-0.45\right.$, $\left.r_{\text {June }}=-0.43, r_{\text {July }}=-0.65, p<0.05\right)$ and $Y$ coordinates $\left(r_{\text {May }}\right.$ $\left.=-0.62, r_{\text {June }}=-0.79, r_{\text {July }}=-0.53, p<0.01\right)$ in each month, as pools with the least conductive water were located in the more sheltered northeastern end of the study area (Online Resource 6a-c).

A total of 179 species belonging to 62 genera were detected from May to July. Of these genera, the majority (73\%) were represented by a maximum of two species. The most diverse genera were Nitzschia (29 spp.) and Navicula (26 spp.). Onethird $(33 \%)$ of all detected species were present in a single month only and the majority (62\%) of these species occurred as a single cell only (Online Resource 7). Half of the detected species occurred every month. In May and June, a few species occupied every pool, while in July, none of the species occupied all pools (Online Resource 8). The pools housed a mixture of freshwater (57\% of all identified species in May-July), brackish (21\%) and marine (14\%) species, and a few species (8\%) typical of both marine and freshwater habitats (Table 2). The majority (67\% in May up to $87 \%$ in July) of the pool communities were dominated by freshwater species in each month, whereas the rest of the pools ( 3 pools in May and 1 pool in June-July) were dominated by brackish species and one pool in May by marine species (Online Resource 9).

The relative proportion of marine, brackish and freshwater species among the pools varied along a spatial gradient (i.e., by either $X$ or $Y$ coordinates) in each month. The proportion of marine species among the pools decreased significantly $\left(r_{\mathrm{s}}=-\right.$ $0.44, p<0.05)$ with $Y$ coordinates in June $\left(r_{\mathrm{s}}=-0.3, p<0.05\right)$ and with $X$ coordinates in July $\left(r_{\mathrm{s}}=-0.53, p<0.01\right)$, while that of brackish species decreased significantly along both $X$ $\left(r_{\mathrm{s}}=-0.44, p<0.05\right)$ and $Y$ coordinates in May $\left(r_{\mathrm{s}}=-0.52, p\right.$ $<0.01$ ) (Online Resource 6a-c). The per-pool proportion of 
Fig. 3 Results for the monthly redundancy analyses and the one with combined data: a May; b June; c July; d all months. Shown are the location of the studied rock pools (numbered from May to July, symbolled in the combined model) in relation to the ordination axes and explanatory variables

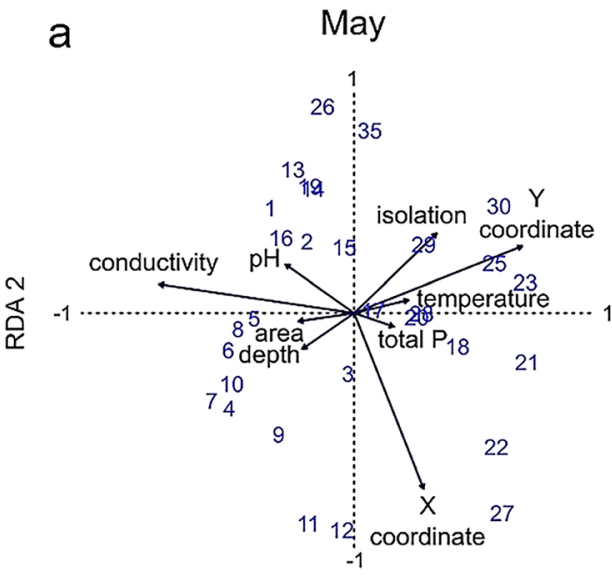

RDA 1

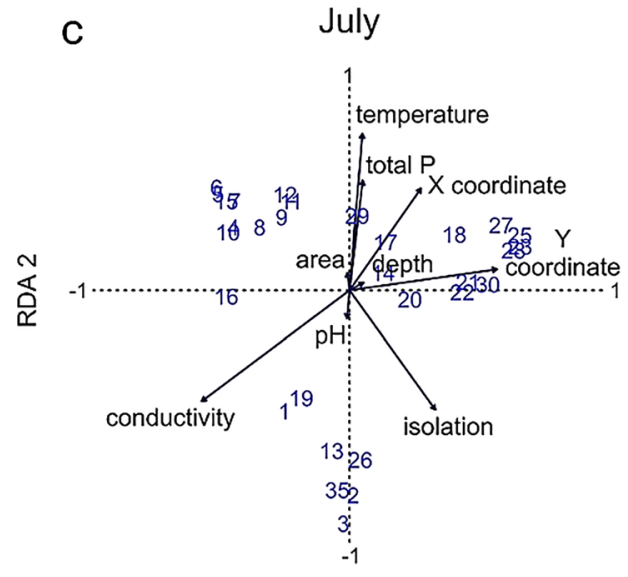

RDA 1

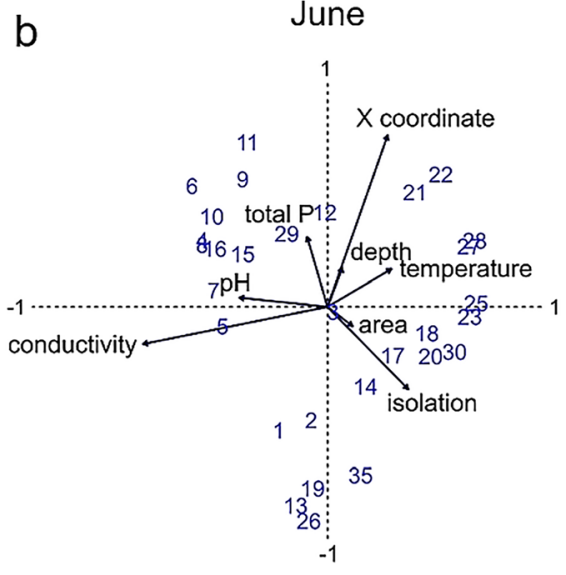

RDA 1

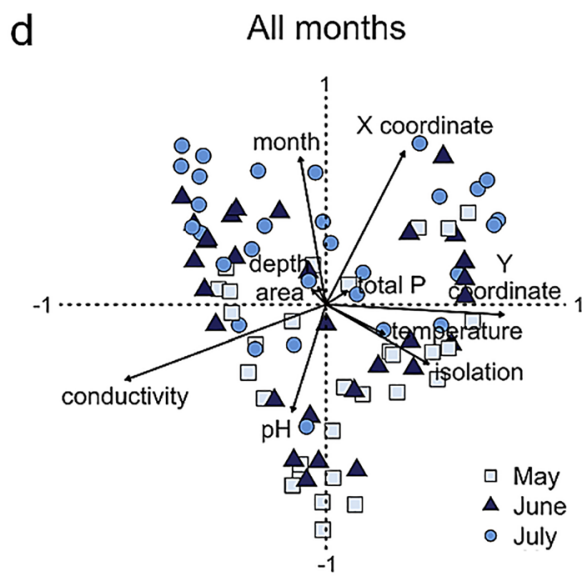

RDA 1 freshwater species increased significantly along both $X\left(r_{\mathrm{s}}=\right.$ $0.49, p<0.01)$ and $Y$ coordinates $\left(r_{\mathrm{s}}=0.55, p<0.01\right)$ in May and along $X$ coordinates in July $\left(r_{\mathrm{s}}=0.48, p<0.01\right)$.

The per-pool proportion of brackish species decreased also significantly $\left(r_{\mathrm{s}}=-0.41, p<0.001\right)$ along a temporal gradient while the proportion of species typical of both marine and freshwater habitats increased significantly $\left(r_{\mathrm{s}}=-0.43, p<\right.$ 0.001 ) from May to July (Online Resource $6 \mathrm{~d}$ ). The total monthly proportion of marine species increased and that of brackish species decreased from May to July (Table 2). The total proportion of freshwater species was rather comparable between the months, peaking in June.
Fig. 4 Results of the monthly Mantel tests. Shown is the change in the Bray-Curtis similarity index along environmental (left) and spatial (right) distance, together with a correlation coefficient for the relationship between species and both spatial and environmental variables, respectively. The significance of correlations is based on the $p$ value: $* p<0.05$, $* * p<0.01, * * * p<0.001$
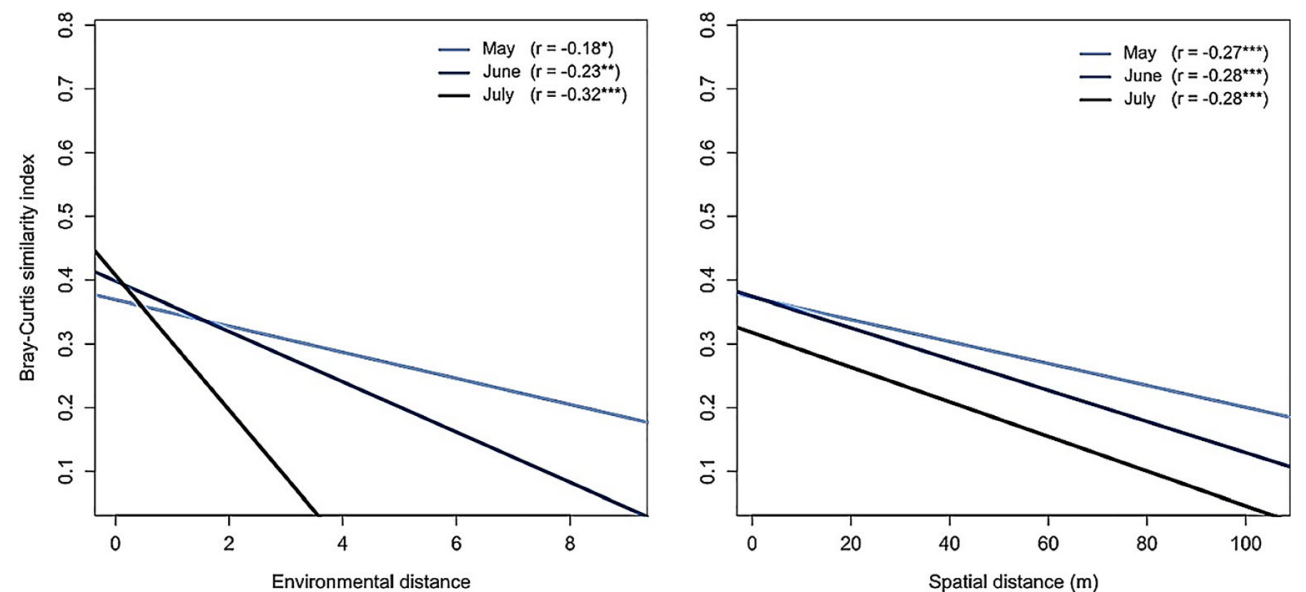


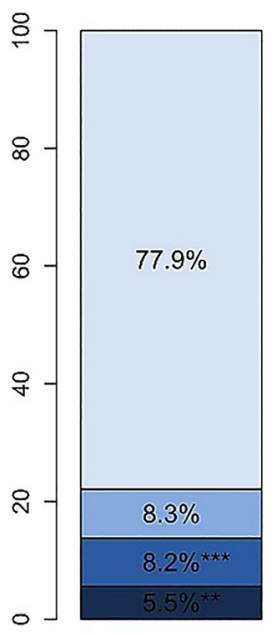

May

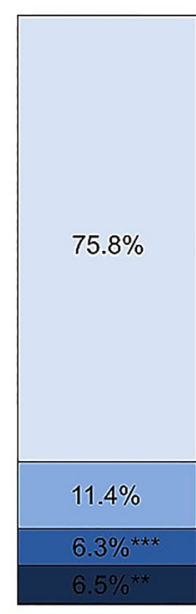

June

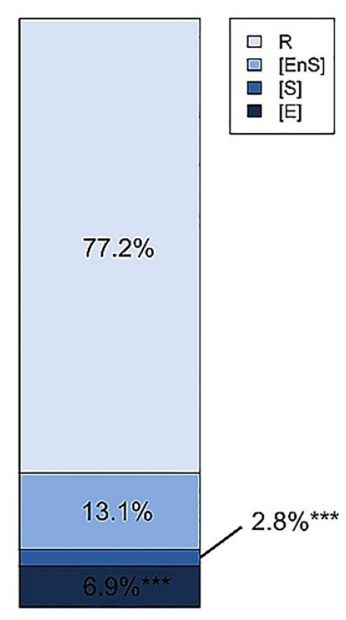

July
Fig. 5 The results of variation partitioning for each study month. Shown are the proportion and statistical significance of the explained variation in species community composition by pure environmental ([E]) and pure spatial ([S]) variables, together with the joint effect of these two variable sets $([\mathrm{E} \cap \mathrm{S}])$. The unexplained proportion of variation in community composition is expressed as a residual variation (R). The significance of pure environmental and pure spatial components is based on the $p$ value of the $F$ test for a redundancy analysis for the two variable groups: $* p<$ $0.05, * * p<0.01, * * * p<0.001$

The factors affecting community composition also varied in time, but conductivity was consistently one of the key factors (Table 3). In May, the community composition was significantly explained by conductivity $(6.6 \%$ of the explained

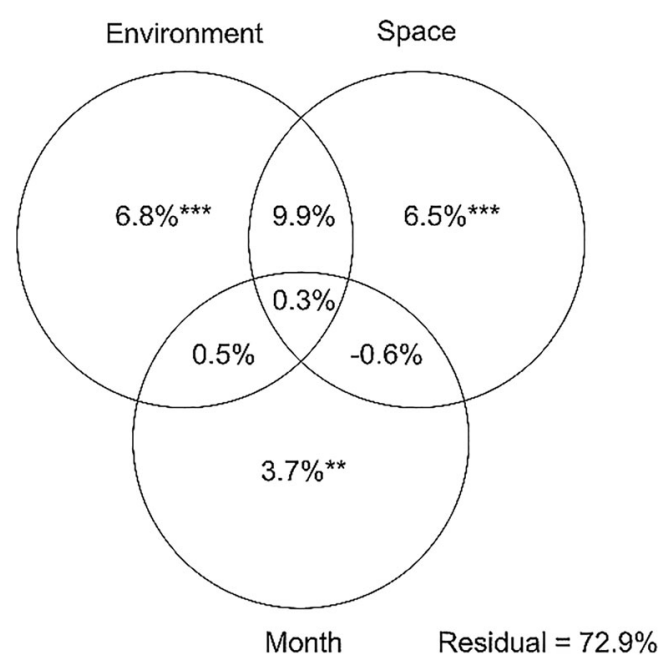

Fig. 6 The results of variation partitioning for the combined monthly data. Shown are the proportion and statistical significance of the explained variation in species community composition by pure environmental (Environment), pure spatial (Space), and pure temporal (Month) variables, together with the joint effects of these three variable sets. The unexplained proportion of the variation is expressed as a residual variation. The significance of pure environmental, pure spatial, and pure temporal components is based on the $p$ value of the $F$ test for a redundancy analysis for each of the three variable groups: ${ }^{*} p<0.05$, $* * p<0.01, * * * p<0.001$
Table 1 Monthly statistics for the environmental variables

\begin{tabular}{|c|c|c|c|c|c|c|}
\hline Month & Variable & Min & Max & Mean & Median & Std. dev. \\
\hline \multirow[t]{8}{*}{ May } & $\begin{array}{l}\text { Total phosphorus } \\
\quad\left(\mu \mathrm{g} \mathrm{L}^{-1}\right)\end{array}$ & 49.1 & 1448.3 & 378.4 & 270.2 & 348.2 \\
\hline & $\mathrm{pH}$ & 8.1 & 9.9 & 9.2 & 9.3 & 0.5 \\
\hline & $\begin{array}{l}\text { Conductivity } \\
\left(\mu \mathrm{S} \mathrm{cm}^{-1}\right)\end{array}$ & 134 & 16,741 & 3964 & 2014 & 4421 \\
\hline & Temperature $\left({ }^{\circ} \mathrm{C}\right)$ & 18.5 & 26.2 & 21.3 & 21.3 & 1.7 \\
\hline & Length (m) & 0.45 & 10.70 & 1.91 & 1.20 & 2.24 \\
\hline & Width (m) & 0.15 & 4.80 & 0.79 & 0.50 & 0.94 \\
\hline & Depth (m) & 0.05 & 0.34 & 0.17 & 0.16 & 0.08 \\
\hline & Area $\left(\mathrm{m}^{2}\right)$ & 0.09 & 33.12 & 2.71 & 0.62 & 6.52 \\
\hline \multirow[t]{8}{*}{ June } & $\begin{array}{l}\text { Total phosphorus } \\
\quad\left(\mu \mathrm{g} \mathrm{L}^{-1}\right)\end{array}$ & 17.3 & 363.1 & 82.1 & 65.3 & 71.4 \\
\hline & $\mathrm{pH}$ & 7.2 & 10.0 & 8.7 & 8.8 & 0.8 \\
\hline & $\begin{array}{l}\text { Conductivity } \\
\left(\mu \mathrm{S} \mathrm{cm}^{-1}\right)\end{array}$ & 62 & 10,754 & 4438 & 3868 & 4005 \\
\hline & Temperature $\left({ }^{\circ} \mathrm{C}\right)$ & 14.8 & 21.3 & 18.7 & 18.9 & 1.6 \\
\hline & Length (m) & 0.65 & 16.20 & 2.54 & 1.74 & 3.00 \\
\hline & Width (m) & 0.20 & 5.40 & 1.00 & 0.64 & 1.03 \\
\hline & Depth (m) & 0.11 & 0.40 & 0.23 & 0.22 & 0.08 \\
\hline & Area $\left(\mathrm{m}^{2}\right)$ & 0.19 & 36.72 & 4.01 & 1.04 & 8.10 \\
\hline \multirow[t]{8}{*}{ July } & $\begin{array}{l}\text { Total phosphorus } \\
\quad\left(\mu \mathrm{g} \mathrm{L}^{-1}\right)\end{array}$ & 22.2 & 724.8 & 181.5 & 139.7 & 165.1 \\
\hline & $\mathrm{pH}$ & 6.7 & 9.5 & 7.9 & 7.9 & 0.6 \\
\hline & $\begin{array}{l}\text { Conductivity } \\
\left(\mu \mathrm{S} \mathrm{cm}^{-1}\right)\end{array}$ & 38 & 14,383 & 3902 & 943 & 4818 \\
\hline & Temperature $\left({ }^{\circ} \mathrm{C}\right)$ & 15.8 & 20.7 & 19.2 & 19.6 & 1.2 \\
\hline & Length (m) & 0.60 & 15.90 & 2.61 & 1.68 & 3.0 \\
\hline & Width (m) & 0.16 & 5.30 & 1.07 & 0.65 & 1.1 \\
\hline & Depth (m) & 0.09 & 0.36 & 0.21 & 0.22 & 0.1 \\
\hline & Area $\left(\mathrm{m}^{2}\right)$ & 0.14 & 34.98 & 4.72 & 1.24 & 9.0 \\
\hline
\end{tabular}

variance, $p<0.001)$ and $X$ coordinates $(3.4 \%, p<0.01)$ in the RDA; the first two ordination axes explained together $28.5 \%$ of the variation in community composition (Fig. 3a). In June, conductivity $(9.1 \%, p<0.001), X$ coordinates $(3.6 \%, p<$ $0.05)$, and $\mathrm{pH}(3.2 \%, p<0.05)$ were significant, and the first two axes explained $32.5 \%$ of the variation (Fig. 3b). In July, conductivity $(10.2 \%, p<0.001)$, temperature $(3.8 \%, p<$ $0.05)$, total $\mathrm{P}(3.7 \%, p<0.05)$, and isolation $(3.7 \%, p<$ $0.05)$ were significant, while the first and the second ordination axes explained $35.6 \%$ of the variation (Fig. 3c). In the combined RDA, several variables were significant; the variation was best explained by conductivity $(7.6 \%, p<0.001), X$ coordinates $(2.6 \%, p<0.001)$, isolation $(2.2 \%, p<0.001)$, and month as a categorical variable $(2.2 \%, p<0.01)$ (Fig. $3 \mathrm{~d})$. The first two axes explained $25.7 \%$ of the variation.

The community similarity decreased significantly with an increase in both spatial and environmental distance in each month even when the other variable group was controlled for. The correlation between similarities and spatial distance was nearly equal $\left(r_{\text {May }}=-0.27, r_{\text {June }}=-0.28, r_{\text {July }}=-0.28\right)$ in 
Table 2 Monthly statistics for the per-pool proportion of diatom species belonging to the four ecological groups according to species-specific salinity tolerances (Taylor et al. 2007; Antón-Garrido et al. 2013; Cantonati et al. 2017). The total monthly proportion of species in each group is also given

\begin{tabular}{|c|c|c|c|c|c|c|c|c|c|c|c|c|}
\hline & \multicolumn{3}{|c|}{ Marine } & \multicolumn{3}{|c|}{ Brackish } & \multicolumn{3}{|c|}{ Freshwater } & \multicolumn{3}{|c|}{ Freshwater/marine } \\
\hline & May & June & July & May & June & July & May & June & July & May & June & July \\
\hline Min & 5.6 & 6.1 & 0.0 & 12.8 & 16.0 & 0.0 & 36.8 & 37.8 & 35.0 & 0.0 & 0.0 & 0.0 \\
\hline Max & 22.2 & 24.0 & 21.2 & 52.6 & 40.0 & 50.0 & 71.8 & 70.8 & 70.0 & 9.1 & 13.3 & 40.0 \\
\hline Mean & 13.3 & 13.5 & 13.1 & 31.3 & 28.3 & 24.0 & 53.1 & 54.4 & 56.3 & 2.2 & 3.9 & 6.6 \\
\hline Median & 12.7 & 13.6 & 13.8 & 29.8 & 27.5 & 23.9 & 52.8 & 54.1 & 57.1 & 1.3 & 3.5 & 5.9 \\
\hline Std. dev. & 4.0 & 4.2 & 4.3 & 9.1 & 5.8 & 8.4 & 8.8 & 7.7 & 7.4 & 2.8 & 3.1 & 7.2 \\
\hline Total & 11.7 & 12.8 & 15.1 & 25 & 21.8 & 19.3 & 56.7 & 60.9 & 58.0 & 6.7 & 4.5 & 7.6 \\
\hline
\end{tabular}

each month, while decrease in similarity along environmental distance increased from May $(r=-0.18)$ to July $(r=-0.32)$ (Fig. 4; Table 4). In May and June, distance decay was stronger for spatial distance than environmental distance, whereas in July, environmental distance was slightly more strongly related with community similarities. The halving distance of community composition was extremely short and decreased from May $(108.7 \mathrm{~m})$ to July $(58.9 \mathrm{~m})$. The initial similarity was nearly equal in May and June $(r=0.37)$, decreasing slightly toward July $(r=0.32)$. The correlation between environmental and spatial distance was rather low in each month $(r \leq 0.43$; Table 4).

The joint effect of environmental and spatial factors consistently explained the largest share (8.3-13.1\%) of the monthly variation in community composition (Fig. 5). The variation explained by pure environmental and pure spatial factors was nearly similar in each month. In May, pure spatial variables accounted for a slightly higher proportion $(8.2 \%)$ of the explained variation than pure environmental variables $(5.5 \%)$, while in June and July, pure environmental variables $(6.5 \%$ and $6.9 \%$ ) explained more of the variation than pure spatial ones (6.3\% and $2.8 \%)$. Temporal variation in the community composition was significant, accounting for $3.7 \%$ of the variation over the whole 3-month period (Fig. 6). The largest share of the variation was jointly explained by environmental and spatial variables $(9.9 \%)$, while their separate effects were nearly equally weak (6.8\% and $6.5 \%$, respectively).

\section{Discussion}

Our study revealed high diatom species turnover in a rock pool metacommunity linked to both environmental heterogeneity and pool spatial distance from the sea through variation
Table 3 Results for the monthly and combined redundancy analyses. Shown is the proportion of explained variance by each statistically significant explanatory variable of the total explained variance in each month, together with their correlation with the species matrix along the first two ordination axes. The significance of the variables is based on the $p$ value of the $F$ test: $* p<0.05, * * p<0.01, * * * p<0.001$

\begin{tabular}{|c|c|c|c|c|c|c|}
\hline Month & Variable & Variance & RDA 1 & RDA 2 & $\operatorname{Pr}(>F)$ & Significance \\
\hline \multirow[t]{2}{*}{ May } & Conductivity & 0.06603 & -0.9148 & 0.1351 & 0.001 & $* * *$ \\
\hline & $X$ coordinate & 0.03403 & 0.3257 & -0.8258 & 0.003 & $* *$ \\
\hline \multirow[t]{3}{*}{ June } & $\mathrm{pH}$ & 0.03191 & -0.4523 & 0.0470 & 0.012 & $*$ \\
\hline & Conductivity & 0.09100 & -0.9489 & -0.1914 & 0.001 & $* * *$ \\
\hline & $X$ coordinate & 0.03606 & 0.3091 & 0.8802 & 0.014 & $*$ \\
\hline \multirow[t]{4}{*}{ July } & Total P & 0.03683 & 0.0679 & 0.5697 & 0.019 & $*$ \\
\hline & Conductivity & 0.10189 & -0.7666 & -0.5748 & 0.001 & $* * *$ \\
\hline & Temperature & 0.03790 & 0.0666 & 0.8112 & 0.013 & $*$ \\
\hline & Isolation & 0.03715 & 0.4444 & -0.6187 & 0.029 & $*$ \\
\hline \multirow[t]{7}{*}{ All } & $\mathrm{pH}$ & 0.01657 & -0.1464 & -0.4626 & 0.001 & $* * *$ \\
\hline & Conductivity & 0.07562 & -0.8676 & -0.3254 & 0.001 & $* * *$ \\
\hline & Depth & 0.01248 & -0.0329 & 0.0747 & 0.003 & $* *$ \\
\hline & $X$ coordinate & 0.02565 & 0.3395 & 0.6630 & 0.001 & $* * *$ \\
\hline & $Y$ coordinate & 0.01387 & 0.7699 & -0.0442 & 0.005 & $* *$ \\
\hline & Isolation & 0.02189 & 0.4437 & -0.2560 & 0.001 & $* * *$ \\
\hline & Month & 0.02245 & -0.1119 & 0.6405 & 0.002 & $* *$ \\
\hline
\end{tabular}


Table 4 Results for the monthly Mantel and partial Mantel tests. Shown are monthly correlation coefficients for pure environmental (Env) and pure spatial variables (Spat), and the corresponding coefficients for these variable groups when the other variable set was controlled for (Env-Spat and Spat-Env, respectively). For a change in dissimilarity index along the spatial distance, the halving distance of community similarity (HD, in meters) is also shown. The initial similarity (IS) refers to the dissimilarity index value at a spatial distance of $1 \mathrm{~m}$. Shown is also the coefficient of correlation between environmental and spatial distance (distance $r$ ) in each month. The statistical significance of the variables is based on the $p$ value: $* p<0.05, * * p<0.01, * * * p<0.001$

\begin{tabular}{lllllll}
\hline Month & Env & Spat & Env-Spat & Spat-Env & Distance $r$ & IS \\
\hline May & $-0.18^{*}$ & $-0.27^{* * *}$ & $-0.17^{*}$ & $-0.26^{* * *}$ & $0.14^{*}$ & 0.37 \\
June & $-0.23^{* *}$ & $-0.28^{* * *}$ & $-0.12^{*}$ & $-0.21^{* *}$ & $0.43^{* * *}$ & 108.7 \\
July & $-0.32^{* * *}$ & $-0.28^{* * *}$ & $-0.29^{* * *}$ & $-0.24 * *$ & $0.19^{* * *}$ & 76.8 \\
\hline
\end{tabular}

in temporal gradient. Given the small spatial scale of the study, the metacommunity was likely mainly structured by mass effect and species sorting, the latter of which was dominated by a conductivity gradient at the marine-freshwater transition zone. The majority of the pool diatoms were freshwater species both temporally and spatially. However, at the ecotone between marine and freshwater habitat, freshwater-tolerant marine species were introduced into the mainly freshwater pools from the nearby sea (Schröder et al. 2015), shifting species composition of the studied communities from freshwater toward more salinity tolerant species along the conductivity gradient.

Although larger-sized species are rarely encountered and hence often underrepresented in microbial samples (Lowe and Pan 1996; Snoeijs et al. 2002) or the presence of some species is sporadic enough to increase the probability for an omission error due to sampling effect (Bottin et al. 2014), the highly uneven local species abundance observed here is a general pattern very typical of diatom communities (Potapova and Charles 2002; Heino et al. 2010) and usually a consequence of the dominance of few species capable of permanently residing in all sites even under frequent environmental disturbance (Dethier 1984). However, due to generally high local species diversity, relative compositional differences between diatom communities are usually captured at a sufficient accuracy with relatively few samples (Eloranta 2004), independent of potential omittance of the most rarely encountered species in a given habitat.

\section{Drivers of diatom community composition}

Water conductivity explained the largest share of variance also in species composition in each month. Several studies support the significance of either conductivity or salinity for both freshwater diatom and coastal rock pool communities (Ganning 1971; Metaxas and Scheibling 1993; Virtanen and Soininen 2012). Either the degree of pool isolation or the distance from the sea was significant for the community composition in each month, with importance of the latter decreasing over time. This might be due to the monthly varying weather conditions. Even minor temporal variations in microclimate may have strong effects on local environmental conditions over a given disturbance regime, directly resulting in relative differences in water depth, wave exposure, and other physicochemical conditions among pools with varying hydroperiod length (Ganning 1971; Jocque et al. 2010). Thus, even under seemingly similar environmental conditions, neighboring habitat patches may well differ in their microscale physicochemistry and hence in community composition (Metaxas and Scheibling 1993; Jenkins and Buikema 1998; Brendonck et al. 2016). Seasonal species succession and temporal changes in water physicochemical variables such as total $\mathrm{P}$, temperature, and $\mathrm{pH}$ were clearly important for the studied communities, expressed by the significance of the categorical "month" variable in the combined RDA model. Especially in June, stronger winds may have lowered the influence of the transverse gradient reflecting spatial variation in water conductivity, extending the influence of seawater from the more exposed southwest further toward the sheltered northeast and distributing brackish species more evenly between the pools. Contrary to the two other months, the distribution of both marine, brackish, and freshwater species among the pools was unaffected by the pool spatial location in June.

We also note that banks of sedimented propagules may have acted as a resisting force for local extinctions often targeted to small aquatic habitats by maintaining viable local populations, further affecting the species composition in the studied communities (Soininen and Meier 2014). The potential influence of such a seed bank on the evolution of a given community is nevertheless likely better discerned in longerterm studies covering several years and growing seasons (Ellegaard and Ribeiro 2018), whereas our study was restricted to a single growing season at a timescale of only 3 months.

\section{Distance decay of community similarity}

Although typically mostly under environmental control, significant distance decay has been documented for diatom assemblages over varying environmental conditions, at multiple temporal and spatial scales, in lentic and lotic waters and along a salinity gradient from freshwater to marine habitats (Soininen 2007; Vanschoenwinkel et al. 2007; Astorga et al. 
2012; Bottin et al. 2014; Virta and Soininen 2017). Both environmental and spatial distances were related with community similarities in each month also here even when the other variable group was controlled for. In May and June, spatial distance decay was stronger than for environmental distance, while in July, community similarities decayed more strongly with the environmental distance. The increase of distance decay with time was more pronounced along environmental distance than along geographical distance, reflecting growing relative importance of the environment for the communities during the study period. Very short and steadily decreasing halving distances were observed from May to July - such values of $60-110 \mathrm{~m}$ are extremely short compared with a global average of over $630 \mathrm{~km}$ across all biotic communities (Soininen et al. 2007) and much shorter than has been reported earlier for freshwater diatoms (Teittinen et al. 2016). Such high species turnover indicates that the salinity gradient acted as a strong filter on the diatom species at this marinefreshwater transition zone.

The proportion of salinity-tolerant species varied the most in May: while the share of marine species exceeded $20 \%$ in few pools and the spatial dominance of brackish species was the highest, the overall proportion of marine species was the lowest and that of brackish species the highest of the 3 months. The dominance of spatial factors and consequent higher variation in species ecological composition in May could be attributed to the rather calm and dry weather lowering water- and windaided dispersal rates between the pools. Wind speed and direction affect aerial carrying capacity of passive dispersers especially on coastal areas, while additional rains enhance wateraided dispersal (Smith 1973; Vanschoenwinkel et al. 2008a). Although random and sudden overflows may act as a strong dispersal agent allowing species to disperse among temporarily connected pools (Jocque et al. 2007; Brendonck et al. 2010), very short duration of these connections may limit significant dispersal. It has been suggested that significant changes in the community composition of passive dispersers occur only beyond $60 \mathrm{~m}$ from the nearest pool independent of a study scale (Vanschoenwinkel et al. 2007). Here, the shortest observed halving distance was little less than $60 \mathrm{~m}$, indicating that compositional changes do happen even beneath this distance limit.

Given the small study extent, dispersal limitation was probably not a major factor contributing to the species composition in the studied communities. In June and July, higher precipitation and wind speed, perhaps accompanied with maturation of faunal dispersal agents such as aquatic invertebrates observed in the field, have likely promoted passive dispersal (Vanschoenwinkel et al. 2008a; Nabout et al. 2009; CastilloEscrivà et al. 2017) and suppressed the importance of dispersal barriers, increasing the influence of water physicochemistry on the communities especially in July. Aerial carrying capacity has been documented to decline as far as $10 \mathrm{~m}$ from a source community (Vanschoenwinkel et al. 2008a) - a distance which the majority of the studied pools were located within. Contrary to May, brackish species were most evenly distributed among the communities in June and dominated only one pool, likely reflecting elevated dispersal rates. Despite the apparent isolation of the pools, either the among-pool distances may have been short enough or the weather conditions suitable for efficient passive dispersal to take place (Teittinen and Soininen 2015). Late appearance of ecologically more specialized species such as Bacillaria paxillifera, Cocconeis scutellum, Epithemia sorex, and E. turgida (Van Dam et al. 1994; Cantonati et al. 2017) likely further explains the growing importance of environmental factors such as salinity, nutrients, and water $\mathrm{pH}$ toward the end of the hydroperiod from June onwards (Potapova and Charles 2002; Vanschoenwinkel et al. 2007; Pandit et al. 2009).

\section{Rock pool metacommunity organization}

The significance of both pure environmental and pure spatial components at such a small study scale points toward mass effect and species sorting as the leading metacommunity types for the studied communities (Cottenie 2005; Soininen and Weckström 2009; Bottin et al. 2016). The highly heterogeneous environmental conditions likely triggered by random disturbance events and a variable hydroperiod gradient serve as a ground for a strong abiotic environmental control by setting demands for a specialized biota (Therriault and Kolasa 2001; O'Neill 2016), while the minor influence of pool isolation and consequently effective passive dispersal over the relative short distances maintain viable communities even in the pools with less favorable ecological conditions (Van der Gucht et al. 2007; Vanschoenwinkel et al. 2008b; Langenheder et al. 2012). Here, an increasing disturbance frequency with time possibly restricted competitive exclusions by maintaining several ecological niches and supporting multiple species with various environmental adaptations along the conductivity gradient (Soininen and Meier 2014). Especially the proportion of brackish species with a tolerance toward weakly saline water decreased significantly with time, while the proportion of species favoring both marine and freshwater habitats increased significantly toward July. Likely accompanied with a growing supply of these latter, more generalist species (e.g., Fragilaria capucina) from the surrounding pools, this may have resulted in less similar communities and in higher species turnover (i.e., shorter halving distance) between the pools with time (Soininen and Heino 2007; Vanschoenwinkel et al. 2013). However, given the relatively high proportion of unexplained variance in community composition in each month, we cannot completely rule out possible effects of neutrality and patch dynamics on the pool metacommunity; rather, our results only suggest mass effect and species sorting as being the archetypes admittedly responsible of the species composition, regardless of the role of the other two in the studied communities. 
We also note that, although we included the most important environmental variables in the analyses, omission of some unmeasured spatially structured environmental variables may have artificially increased the relative importance of pure spatial variables in explaining the pool communities (Liu et al. 2016; Soininen 2016).

\section{Conclusions}

The studied rock pools were environmentally heterogeneous, with high spatial and temporal variation in water physicochemical characteristics. Together with dispersal processes, such high environmental heterogeneity also supported high species turnover in the metacommunity. The results give support for mass effect and species sorting as the possible leading metacommunity types for the studied rock pool communities, along with potential yet likely minor contribution of patch dynamics and neutrality. The highly variable and disturbed physicochemical environment and efficient passive dispersal over the relatively short amongpool distances, assisted with suitable weather conditions, likely serve as an additional species supply from the neighboring pools. These results also highlight the high potential of rock pools as a model system for metacommunity studies along steep environmental gradients over time.

Acknowledgements We thank the two anonymous reviewers for the constructive and helpful comments on the earlier version of the manuscript.

Funding information Open access funding provided by University of Helsinki including Helsinki University Central Hospital. This study was funded by the Finnish Cultural Foundation.

\section{Compliance with ethical standards}

Conflict of interest The authors declare that they have no conflict of interest.

Ethical approval No animal testing was performed during this study.

Data availability The datasets generated during and/or analyzed during the current study are available from the corresponding author on reasonable request.

Open Access This article is distributed under the terms of the Creative Commons Attribution 4.0 International License (http:// creativecommons.org/licenses/by/4.0/), which permits unrestricted use, distribution, and reproduction in any medium, provided you give appropriate credit to the original author(s) and the source, provide a link to the Creative Commons license, and indicate if changes were made.

\section{References}

Antón-Garrido B, Romo S, Villena MJ (2013) Diatom species composition and indices for determining the ecological status of coastal
Mediterranean Spanish lakes. Anales Jard Bot Madrid 70:122135. https://doi.org/10.3989/ajbm.2373

Astorga A, Oksanen J, Luoto M, Soininen J, Virtanen R, Muotka T (2012) Distance decay of similarity in freshwater communities: do macro- and microorganisms follow the same rules? Glob Ecol and Biogeogr 21:365-375. https://doi.org/10.1111/j.1466-8238.2011. 00681.x

Azeria ET, Kolasa J (2008) Nestedness, niche metrics and temporal dynamics of a metacommunity in a dynamic natural model system. Oikos 117:1006-1019. https://doi.org/10.1111/j.2008.0030-1299. 16529.x

Blaustein L, Schwartz SS (2001) Why study ecology in temporary pools? Israel J Zool 47:303-312. https://doi.org/10.1092/ckmu-q2pm-htgcp9c8

Borcard D, Legendre P, Drapeau P (1992) Partialling out the spatial component of ecological variation. Ecology 73:1045-1055. https://doi. org/10.2307/1940179

Bottin M, Soininen J, Ferrol M, Tison-Rosebery J (2014) Do spatial patterns of benthic diatom assemblages vary across regions and years? Freshw Sci 33:402-416. https://doi.org/10.1086/675726

Bottin M, Soininen J, Alard D, Rosebery J (2016) Diatom cooccurrence shows less segregation than predicted from niche modeling. PLoS ONE 11(4):e0154581. https://doi.org/10.1371/journal.pone. 0154581

Bray RJ, Curtis JT (1957) An ordination of the upland forest communities of southern Wisconsin. Ecol Monogr 27:325-349. https://doi.org/ $10.2307 / 1942268$

Brendonck L, Jocque M, Hulsmans A, Vanschoenwinkel B (2010) Pools 'on the rocks': freshwater rock pools as model system in ecological and evolutionary research. Limnetica 29:25-40

Brendonck L, Lanfranco S, Timms B, Vanschoenwinkel B (2016) Invertebrates in rock pools. In: Baxter D, Boix D (eds) Invertebrates in freshwater wetlands. An international perspective on their ecology. Springer International Publishing, Switzerland. https://doi.org/10.1007/978-3-319-24978-0_2

Cantonati M, Kelly MG, Lange-Bertalot H (eds) (2017) Freshwater benthic diatoms of Central Europe. 942 p. Koeltz Botanical Books

Castillo-Escrivà A, Aguilar-Alberola JA, Mesquita-Joanes F (2017) Spatial and environmental effects on a rock-pool metacommunity depend on landscape setting and dispersal mode. Freshwater Biol 62:1004-1011. https://doi.org/10.1111/fwb.12920

Chave J (2004) Neutral theory and community ecology. Ecol Lett 7:241253. https://doi.org/10.1111/j.1461-0248.2003.00566.x

Cottenie K (2005) Integrating environmental and spatial processes in ecological community dynamics. Ecol Lett 8:1175-1182. https:// doi.org/10.1111/j.14610248.2005.00820.x

Cottenie K, De Meester L (2004) Metacommunity structure: synergy of biotic interactions as selective agents and dispersal as fuel. Ecology 85:114-119. https://doi.org/10.1890/03-3004

De Meester L, Declerck S, Stoks R, Louette G, Van De Meutter F, De Bie T, Michels E, Brendonck L (2005) Ponds and pools as model systems in conservation biology, ecology and evolutionary biology. Aquat Conserv 15:715-725. https://doi.org/10.1002/aqc.748

Dethier MN (1984) Disturbance and recovery in intertidal pools: maintenance of mosaic patterns. Ecol Monogr 54:99-118. https://doi.org/ $10.2307 / 1942457$

Ellegaard M, Ribeiro S (2018) The long-term persistence of phytoplankton resting stages in aquatic 'seed banks'. Biol Rev 93:166-183. https://doi.org/10.1111/brv.12338

Eloranta P (2004) Vesien tilan arvioinnissa käytettävät biologiset tutkimukset. In: Ruoppa M, Heinonen P (eds) Suomessa käytetyt biologiset vesitutkimusmenetelmät. 119 p. Finnish Environment Institute, Helsinki

EN 13946 (2003) Water quality - guidance standard for the routine sampling and pre-treatment of benthic diatoms from rivers. European Committee for Standardization, Geneva 
FMI (2017) Climate statistics from Kumpula meteorological station. Climate service, Finnish Meteorological Institute, Helsinki

Ganning B (1971) Studies on chemical, physical and biological conditions in Swedish rock pool ecosystems. Ophelia 9:51-105. https:// doi.org/10.1080/00785326.1971.10430090

Giraudoux P, Antonietti J-P, Beale C, Pleydell D, Treglia M (2018) pgirmess: spatial analysis and data mining for field ecologists. $\mathrm{R}$ package version 1.6.9. http://CRAN.R-project.org/package $=$ pgirmess. Accessed 28 June 2018

Hanski I, Gilpin M (1991) Metapopulation dynamics: a brief history and conceptual domain. Biol J Linn Soc 42:3-16. https://doi.org/10. 1111/j.1095-8312.1991.tb00548.x

Harrell FE Jr (2018) Hmisc: Harrell miscellaneous. R package version 4: 1-1 http://CRAN.R-project.org/package=Hmisc. Accessed 28 June 2018

Heino J, Bini LM, Karjalainen SM, Mykrä H, Soininen J, Vieira LCG, Diniz-Filho JAF (2010) Geographical patterns of micro-organismal community structure: are diatoms ubiquitously distributed across boreal streams? Oikos 119:129-137. https://doi.org/10.1111/j. 1600-0706.2009.17778.x

Hubbell SP (2001) The unified neutral theory of biodiversity and biogeography. Princeton University Press, Princeton

Jenkins DG, Buikema AL (1998) Do similar communities develop in similar sites? A test with zooplankton structure and function. Ecol Monogr 68:421-443. https://doi.org/10.1890/0012-9615(1998) 068[0421:DSCDIS]2.0.CO;2

Jocque M, Martens K, Riddoch B, Brendonck L (2006) Faunistics of ephemeral rock pools in southeastern Botswana. Fund Appl Limnol / Arch für Hydrobiol 165:415-431. https://doi.org/10. 1127/0003-9136/2006/0165-0415

Jocque M, Riddoch BJ, Brendonck L (2007) Successional phases and species replacement in freshwater rock pools: towards a biological definition of ephemeral systems. Freshwater Biol 52:1734-1744. https://doi.org/10.1111/j.1365-2427.2007.01802.x

Jocque M, Vanschoenwinkel B, Brendonck L (2010) Freshwater rock pools: habitat characterization, faunal diversity and conservation value. Freshwater Biol 55:1587-1602. https://doi.org/10.1111/j. 1365-2427.2010.02402.x

Kelly MG, Cazaubon A, Coring E, Dell'Uomo A, Ector L, Goldsmith B, Guasch H, Hürlimann J, Jarlman A, Kawecka B, Kwandrans J, Laugaste R, Lindstrøm E-A, Leitao M, Marvan P, Padisák J, Pipp E, Prygiel J, Rott E, Sabater S, van Dam H, Vizinet J (1998) Recommendations for the routine sampling of diatoms for water quality assessments in Europe. J Appl Phycol 10:215-224. https:// doi.org/10.1023/A:1008033201227

Krammer K, Lange-Bertalot H (1986-1991) Bacillariophyceae. Süßwasserflora von Mitteleuropa 2:1-4. Gustav Fischer Verlag, Stuttgart.

Langenheder S, Berga M, Östman Ö, Székely AJ (2012) Temporal variation of $\beta$-diversity and assembly mechanisms in a bacterial metacommunity. ISME J 6:1107-1114. https://doi.org/10.1038/ ismej.2011.177

Legendre P (1993) Spatial autocorrelation: trouble or new paradigm? Ecology 74:1659-1673. https://doi.org/10.2307/1939924

Legendre P, Legendre L (2012) Numerical ecology, 3rd edn. Elsevier, Oxford

Leibold MA, Holyoak M, Mouquet N, Amarasekare P, Chase JM, Hoopes MF, Holt RD, Shurin JB, Law R, Tilman D, Loreau M, Gonzalez A (2004) The metacommunity concept: a framework for multi-scale community ecology. Ecol Lett 7:601-613. https://doi. org/10.1111/j.1461-0248.2004.00608.x

Liu S, Xie G, Wang L, Cottenie K, Liu D (2016) Different roles of environmental variables and spatial factors in structuring stream benthic diatom and macroinvertebrate in Yangtze river delta, China. Ecol Indic 61:602-611. https://doi.org/10.1016/j.ecolind. 2015.10.011
Logue JB, Lindström ES (2008) Biogeography of bacterioplankton in inland waters. Freshw Rev 1:99-114. https://doi.org/10.1608/FRJ1.1.9

Logue JB, Mouquet N, Peter H, Hillebrand H, The metacommunity working group (2011) Empirical approaches to metacommunities: a review and comparison with theory. Trends Ecol Evol 26:482491. https://doi.org/10.1016/j.tree.2011.04.009

Lowe RL, Pan Y (1996) Benthic algal communities as biological monitors. In: Stevenson RJ, Bothwell ML, Lowe RL (eds) Algal ecology. Freshwater benthic ecosystems. 753 p. Academic press, Cambridge

Mantel N (1967) The detection of disease clustering and a generalized regression approach. Cancer Res 27:209-220

Martiny JBH, Bohannan BJM, Brown JH, Colwell RK, Fuhrman JA, Green JL, Horner-Devine MC, Kane M, Adams Krumins J, Kuske CR, Morin PJ, Naeem S, Øvreås L, Reysenbach A-L, Smith VH, Staley JT (2006) Microbial biogeography: putting microorganisms on the map. Nat Rev Microbiol 4:102-112. https://doi.org/10.1038/ nrmicro 1341

Meier S, Soininen J (2014) Phytoplankton metacommunity structure in subarctic rock pools. Aquat Microb Ecol 73:81-91. https://doi.org/ 10.3354/ame01711

Metaxas A, Scheibling RE (1993) Community structure and organization of tidepools. Mar Ecol Prog Ser 98:187-198. https://doi.org/10. 3354/meps098187

Methratta ET (2004) Top-down and bottom-up factors in tidepool communities. J Exp Mar Biol and Ecol 299:77-96. https://doi.org/10. 1016/j.jembe.2003.09.004

Moran PAP (1950) Notes on continuous stochastic phenomena. Biometrika 37:17-23. https://doi.org/10.2307/2332142

Nabout JC, Siqueira T, Bini LM, de Nogueira IS (2009) No evidence for environmental and spatial processes in structuring phytoplankton communities. Acta Oecol 35:720-726. https://doi.org/10.1016/j. actao.2009.07.002

National Land Survey of Finland (2018) Paikkatietoikkuna. https://kartta. paikkatietoikkuna.fi/. Accessed 2 May 2018

O'Neill BJ (2016) Community disassembly in ephemeral ecosystems. Ecology 97:3285-3292. https://doi.org/10.1002/ecy.1604

Oksanen J, Blanchet FG, Friendly M, Kindt R, Legendre P, McGlinn D, Minchin PR, O’Hara RB, Simpson GL, Solymos P, Stevens MHH, Szoecs E, Wagner H (2018) vegan: community ecology package. R package version 2.5-2. R Foundation for Statistical Computing, Vienna https://cran.r-project.org/

Padial AA, Ceschin F, Declerck SAJ, De Meester L, Bonecker CC, Lansac-Tôha FA, Rodrigues L, Rodrigues LC, Train S, Velho LFM, Bini LM (2014) Dispersal ability determines the role of environmental, spatial and temporal drivers of metacommunity structure. PLoS ONE 9(10):e111227. https://doi.org/10.1371/journal.pone. 0111227

Pandit SN, Kolasa J, Cottenie K (2009) Contrasts between habitat generalists and specialists: an empirical extension to the basic metacommunity framework. Ecology 90:2253-2262. https://doi. org/10.1890/08-0851.1

Potapova M, Charles DF (2002) Benthic diatoms in USA rivers: distributions along spatial and environmental gradients. J Biogeogr 29: 167-187. https://doi.org/10.1046/j.1365-2699.2002.00668.x

Pulliam HR (2000) On the relationship between niche and distribution. Ecol Lett 3:349-361. https://doi.org/10.1046/j.1461-0248.2000. 00143.x

R Core Team (2018) The R project for statistical computing. https://www. r-project.org/. Accessed 28 June 2018

Schröder M, Sondermann M, Sures B, Hering D (2015) Effects of salinity gradients on benthic invertebrate and diatom communities in a German lowland river. Ecol Indic 57:236-248. https://doi.org/10. 1016/j.ecolind.2015.04.038

SFS-EN ISO 11905-1 (1998) Veden laatu. Typen määritys. Osa 1: peroksidisulfaattihapetus. Suomen standardisoimisliitto, Helsinki 
SFS-EN ISO 6878 (2004) Veden laatu. Fosforin määritys spektrometrisellä ammoniummolybdaattimenetelmällä. Suomen standardisoimisliitto, Helsinki

Shapiro SS, Wilk MB (1965) An analysis of variance test for normality (complete samples). Biometrika 52:591-611. https://doi.org/10. 1093/biomet/52.3-4.591

Shmida A, Wilson MV (1985) Biological determinant of species diversity. J Biogeogr 12:1-20. https://doi.org/10.2307/2845026

Smith PE (1973) The effects of some air pollutants and meteorological conditions on airborne algae and protozoa. J Air Pollut Control Assoc 23:876-880. https://doi.org/10.1080/00022470.1973. 10469858

Smucker NJ, Vis ML (2011) Contributions of habitat sampling and alkalinity to diatom diversity and distributional patterns in streams: implications for conservation. Biodivers Conserv 20:643-661. https:// doi.org/10.1007/s10531-010-9972-0

Snoeijs P, Busse S, Potapova M (2002) The importance of diatom cell size in community analysis. J Phycol 38:265-272. https://doi.org/ 10.1046/j.1529-8817.2002.01105.x

Soininen J (2007) Environmental and spatial control of freshwater diatoms - a review. Diatom Res 22:473-490. https://doi.org/10.1080/ 0269249X.2007.9705724

Soininen J (2016) Spatial structure in ecological communities - a quantitative analysis. Oikos 125:160-166. https://doi.org/10.1111/oik. 02241

Soininen J, Heino J (2007) Variation in niche parameters along the diversity gradient of unicellular eukaryote assemblages. Protist 158:181191. https://doi.org/10.1016/j.protis.2006.11.002

Soininen J, Meier S (2014) Phytoplankton richness is related to nutrient availability, not to pool size, in a subarctic rock pool system. Hydrobiologia 740:137-145. https://doi.org/10.1007/s10750-0141949-7

Soininen J, Weckström J (2009) Diatom community structure along environmental and spatial gradients in lakes and streams. Fund Appl Limnol / Arch für Hydrobiol 174:205-213. https://doi.org/10.1127/ 1863-9135/2009/0174-0205

Soininen J, McDonald R, Hillebrand H (2007) The distance-decay of similarity in ecological communities. Ecography 30:3-12. https:// doi.org/10.1111/j.0906-7590.2007.04817.x

Srivastava DS, Kolasa J, Bengtsson J, Gonzalez A, Lawle SP, Miller TE, Munguia P, Romanuk T, Schneider DC, Trzcinski MK (2004) Are natural microcosms useful model systems for ecology? Trends Ecol Evol 19:379-384. https://doi.org/10.1016/j.tree.2004.04.010

Taylor JC, Harding WR, Archibald CGM (2007) An illustrated guide to some common diatom species from South Africa. 225 p. WRC report TT 282/07

Teittinen A, Soininen J (2015) Testing the theory of island biogeography for microorganisms - patterns for spring diatoms. Aquat Microb Ecol 75:239-250. https://doi.org/10.3354/ame01759

Teittinen A, Kallajoki L, Meier S, Stigzelius T, Soininen JH (2016) The roles of elevation and local environmental factors as drivers of diatom diversity in subarctic streams. Freshwater Biol 61:1509-1521. https://doi.org/10.1111/fwb.12791

ter Braak CJF (1994) Canonical community ordination. Part I: basic theory and linear methods. Ecoscience 1:127-140. https://doi.org/10. 1080/11956860.1994.11682237
Therriault TW, Kolasa J (2001) Desiccation frequency reduces species diversity and predictability of community structure in coastal rock pools. Israel J Zool 47:477-489. https://doi.org/10.1560/BWWADTXB-LBJK-5GV5

Van Dam H, Mertens A, Sinkeldam J (1994) A coded checklist and ecological indicator values of freshwater diatoms from the Netherlands. Neth J Aquat Ecol 28:117-133. https://doi.org/10. 1007/BF02334251

Van der Gucht K, Cottenie K, Muylaert K, Vloemans N, Cousin S, Declerck S, Jeppesen E, Conde-Porcuna JM, Schwenk K, Zwart G, Degans H, Vyverman W, De Meester L (2007) The power of species sorting: local factors drive bacterial community composition over a wide range of spatial scales. Proc Natl Acad of Sci USA 104: 20404-20409. https://doi.org/10.1073/pnas.0707200104

Vanormelingen P, Cottenie K, Michels E, Muylaert K, Vyverman W, De Meester L (2008) The relative importance of dispersal and local processes in structuring phytoplankton communities in a set of highly interconnected ponds. Freshwater Biol 53:2170-2183. https://doi. org/10.1111/j.1365-2427.2008.02040.x

Vanschoenwinkel B, De Vries C, Seaman MT, Brendonck L (2007) The role of metacommunity processes in shaping invertebrate rock pool communities along a dispersal gradient. Oikos 116:1255-1266. https://doi.org/10.1111/j.0030-1299.2007.15860.x

Vanschoenwinkel B, Gielen S, Seaman M, Brendonck L (2008a) Any way the wind blows - frequent wind dispersal drives species sorting in ephemeral aquatic communities. Oikos 117:125-134. https://doi. org/10.1111/j.2007.0030-1299.16349.x

Vanschoenwinkel B, Gielen S, Vandewaerde H, Brendonck L (2008b) Relative importance of different dispersal vectors for small aquatic invertebrates in a rock pool metacommunity. Ecography 31:567577. https://doi.org/10.1111/j.0906-7590.2008.05442.x

Vanschoenwinkel B, Waterkeyn A, Jocqué M, Boven L, Seaman M, Brendonck L (2010) Species sorting in space and time - the impact of disturbance regime on community assembly in a temporary pool metacommunity. J North Am Benthol Soc 29:1267-1278. https:/ doi.org/10.1899/09-114.1

Vanschoenwinkel B, Buschke FT, Brendonck L (2013) Disturbance regime alters the impact of dispersal on alpha and beta diversity in a natural metacommunity. Ecology 94:2547-2557. https://doi.org/10. $1890 / 12-1576.1$

Virta L, Soininen J (2017) Distribution patterns of epilithic diatoms along climatic, spatial and physicochemical variables in the Baltic Sea. Helgol Mar Res 71:16. https://doi.org/10.1186/s10152-017-0496

Virtanen L, Soininen J (2012) The roles of environment and space in shaping stream diatom communities. Eur J Phycol 47:160-168. https://doi.org/10.1080/09670262.2012.682610

Wetzel CE, de Bicudo DC, Ector L, Lobo EA, Soininen J, Landeiro VL, Bini LM (2012) Distance decay of similarity in neotropical diatom communities. PLoS ONE 7(9):e45071. https://doi.org/10.1371/ journal.pone.0045071

Publisher's note Springer Nature remains neutral with regard to jurisdictional claims in published maps and institutional affiliations. 